\title{
Induced Resistance as a Mechanism of Biological Control by Lysobacter enzymogenes Strain C3
}

\author{
Ozlem Kilic-Ekici and Gary Y. Yuen
}

Department of Plant Pathology, University of Nebraska, Lincoln 68583.

Accepted for publication 28 April 2003.

\begin{abstract}
Kilic-Ekici, O., and Yuen, G. Y. 2003. Induced resistance as a mechanism of biological control by Lysobacter enzymogenes strain C3. Phytopathology 93:1103-1110.

Induced resistance was found to be a mechanism for biological control of leaf spot, caused by Bipolaris sorokiniana, in tall fescue (Festuca arundinacea) using the bacterium Lysobacter enzymogenes strain C3. Resistance elicited by C3 suppressed germination of B. sorokiniana conidia on the phylloplane in addition to reducing the severity of leaf spot. The pathogen-inhibitory effect could be separated from antibiosis by using heat-inactivated cells of $\mathrm{C} 3$ that retained no antifungal activity. Application of live or heat-killed cells to tall fescue leaves resulted only

suppression of conidial germination and leaf spot development even when pathogen inoculation was delayed 15 days after bacterial treatment. When C3 population levels and germination of pathogen conidia was examined on leaf segments, germination percentage was reduced on all segments from C3-treated leaves compared with segments from nontreated leaves, but no dose-response relationship typical of antagonism was found. Induced resistance by $\mathrm{C} 3$ was not host or pathogen specific; foliar application of heat-killed C3 cells controlled B. sorokiniana on wheat and also was effective in reducing the severity of brown patch, caused by Rhizoctonia solani, on tall fescue. Treatments of tall fescue foliage or roots with $\mathrm{C} 3$ resulted in significantly elevated peroxidase activity compared with the control.
\end{abstract} in localized resistance confined to the treated leaf, whereas treatment of roots resulted in systemic resistance expressed in the foliage. The effects of foliar and root applications of C3 were long lasting, as evidenced by
Additional keywords: Cochliobolus sativus, induced systemic resistance, systemic acquired resistance.
Lysobacter enzymogenes strain C3 is a field-effective bacterial biocontrol agent against Bipolaris leaf spot (caused by Bipolaris sorokiniana) and brown patch (incited by Rhizoctonia solani) in turfgrass $(33,34)$, and against rust (Uromyces appendiculatus) in common bean (32). It was identified as a strain of Stenotrophomonas maltophilia on the basis of biochemical tests (8); however, recent analysis of $16 \mathrm{~S}$ rDNA and other traits in $\mathrm{C} 3$ revealed that it is, instead, a strain of the gliding bacterium L. enzymogenes (26). Control of Bipolaris leaf spot and brown patch by $\mathrm{C} 3$ was associated with suppression of germination of $B$. sorokiniana conidia (34) and inhibition of epiphytic hyphal growth in $R$. solani (33), respectively. Control of $B$. sorokiniana by $\mathrm{C} 3$ was attributed in part to chitinase production on the leaf surface, as evidenced by reduced biocontrol activity in chitinase-deficient mutants (35). Further evidence of the role of $\mathrm{C} 3$ chitinases was found in the inhibition of conidia germination in $B$. sorokiniana by partially purified chitinases from C3 (36). In these studies, chitinase activity could not account for all the pathogen and disease inhibitory action of $\mathrm{C} 3$, suggesting that additional mechanisms were involved. When the spatial distribution of $\mathrm{C} 3$ on individual grass shoots in the field was examined, the bacterium was detected sporadically on distal portions of leaf blades and occurred primarily on lower portions of shoots $(7,9)$; this spatial pattern was not consistent with effective biological control in the field through antagonism, raising the possibility that a nonspatially dependent mechanism such as induced resistance $(24,27)$ also might be involved.

Induced resistance is an important mechanism of biological control by a number of strains of plant growth-promoting rhizo-

Corresponding author: G. Y. Yuen; E-mail address: gyuen1@unl.edu

Publication no. P-2003-0703-01R

(c) 2003 The American Phytopathological Society bacteria (PGPR) applied to roots or seed $(17,20,27,28)$. It also can be induced by foliar application of plant-pathogenic bacteria (24), their metabolites $(25,30)$, and metabolites produced by saprophytic bacterial strains (23). However, there are only few reports of it being a mechanism of biological control by live bacterial agents applied to the phylloplane (1-3). Induced resistance has been associated with numerous plant response mechanisms (11); although there is no single host response at the biochemical or genetic level that is activated by all elicitors, peroxidase activity was associated with many cases of resistance elicited by strains of PGPR (20) and saprophytic phyllosphere bacteria (1-3), as well as resistance induced by pathogens and chemicals $(11,12,22)$. In addition to using a biochemical marker such as peroxidase activity, verification of induced resistance is dependent upon satisfying a set of criteria common to different systems of induced resistance $(23,27)$.

The main objective of this study was to determine whether or not induced resistance is a mechanism of disease suppression by C3. Our goal was to apply some of the criteria for induced resistance $(23,27)$ to biological control of $B$. sorokiniana by $\mathrm{C} 3$. The criteria we tested were (i) disease inhibition in the absence of direct antagonism to the pathogen, (ii) systemic as well as local protection, (iii) requirement for a time interval between treatment with an inducer and onset of protection, (iv) absence of a doseresponse relationship typical of antagonism, and (v) nonspecificity of the protection in regards to the host plant and target pathogen. Another goal was to obtain direct evidence for a host response to C3 by assaying peroxidase activity. Some preliminary results have been published (31).

\section{MATERIALS AND METHODS}

General microbiological and plant culture methods. A spontaneous mutant isolate of strain $\mathrm{C} 3$ resistant to rifampicin (8) was used in all experiments. It was cultured on $20 \%$ tryptic soy 
agar (TSA; Sigma-Aldrich, St. Louis) at $25^{\circ} \mathrm{C}$ for 2 days and the resultant cells were suspended in sterile distilled water (SDW). The cells were washed twice by centrifugation $(15,000 \times g$; $20 \mathrm{~min}$ ) and resuspension in SDW. Cell concentrations were

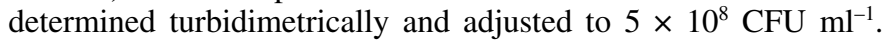
Distilled water, rather than commonly used phosphate buffer, was used for suspending cells to avoid induction of resistance by phosphates (15). The surfactant Soydex 937 (Setre Chemical Company, Memphis, TN), which did not induce resistance in preliminary tests, was added to cell suspensions at $0.25 \%$ ( $\mathrm{vol} / \mathrm{vol})$ to facilitate cell dispersal when applied to leaf surfaces. The surfactant also was added at the same concentration to distilled water, which served as the control in all experiments.

To determine population levels of C3 on leaves, leaf segments were washed in sterile potassium phosphate buffer $(0.01 \mathrm{M}, \mathrm{pH} 7)$, dilutions were plated on a selective medium for C3 (20\% TSA amended with cycloheximide at $200 \mu \mathrm{g} / \mathrm{ml}$, benomyl at $12.5 \mu \mathrm{g} / \mathrm{ml}$, amphotericin B at $2 \mu \mathrm{g} / \mathrm{ml}$, and rifampicin at $100 \mu \mathrm{g} / \mathrm{ml}$ ), and colonies were counted after 3 days. C3 population sizes were expressed as $\log _{10}(\mathrm{CFU}+1)$ per segment.

$B$. sorokiniana, isolated from Kentucky bluegrass, was cultured in thrice-autoclaved tall fescue seeds (100 g in 500-ml flasks) to produce conidia. These cultures were incubated at $23^{\circ} \mathrm{C}$ under $12 \mathrm{~h}$ of diurnal light for 1 month. B. sorokiniana-infested seed were air dried for 3 days, and pathogen conidia then were separated from seed and mycelia by sieving through three mesh screens (300-, 150-, and 45- $\mu \mathrm{m}$ opening size). Conidia were collected and stored under desiccation at $4{ }^{\circ} \mathrm{C}$ until used as inoculum. Germination frequency of the conidia was determined on water agar prior to each experiment. Dry conidia were dusted onto plants, using either a glass petri dish or a glass vial covered with $150-\mu \mathrm{m}$ opening-size mesh screen. To measure germination frequency of conidia inoculated onto leaves, leaf segments were placed in microcentrifuge tubes and washed with $0.5 \mathrm{ml}$ of potassium phosphate buffer $(0.01 \mathrm{M}, \mathrm{pH} 7)$ using gentle agitation with a pipette tip and vortexing two times for $5 \mathrm{~s}$. A 100- $\mu$ l volume of wash was mixed in a well of a microtiter plate first with $50 \mu \mathrm{l}$ of fixative solution $(13 \mathrm{ml}$ of formaline and $5 \mathrm{ml}$ of acetic acid in $200 \mathrm{ml}$ of $50 \%$ ethyl alcohol) and then with $5 \mu \mathrm{l}$ of cotton blue $(0.05 \mathrm{~g}$ of cotton blue and $20 \mathrm{~g}$ of phenol crystals in $20 \mathrm{ml}$ of lactic acid and $40 \mathrm{ml}$ of glycerol) to stain fungal conidia and hyphae. Total numbers of germinated and nongerminated conidia in the well were counted under a dissecting microscope at $\times 120$ magnification. A conidium was considered to have germinated when the length of its germ tube was at least one third the length of the conidium.

Tall fescue (Festuca arunidinacea Schreb.) cv. Kentucky-31 was used in all experiments involving pots of turf. To produce turf, 50 viable seed were planted in $10-\mathrm{cm}$-diameter pots containing a steam-pasteurized potting medium (Sharpsburg silt clay loam, vermiculite, and sand mixed in equal volumes), and the seedlings were grown in a greenhouse for 5 to 6 weeks. The pots were watered daily with a nutrient solution (20-10-20 Peat-Lite Special, Scotts-Sierra Horticultural Co., Marysville, OH), and the plants were clipped to a height of $8 \mathrm{~cm}$ every 7 days. Some experiments involved individual tall fescue plants. To obtain genetic uniformity among these plants, a clonal line that originated from a single plant of cv. Mustang was used. The clonal line was propagated vegetatively by rooting shoots in potting medium for 3 weeks. Single plants were transplanted into potting medium contained in 140-ml plastic pots, and grown for two more weeks in a growth chamber. Two days prior to each experiment, turf or single plants were clipped to $5 \mathrm{~cm}$ in height and the pots were transferred to a growth chamber with a 12 -h photoperiod $\left(25^{\circ} \mathrm{C}\right.$ and 60 to $75 \%$ relative humidity during the light period, $15^{\circ} \mathrm{C}$ and $>93 \%$ relative humidity during the dark period). Growth chamber conditions were regulated by procedures described by Yuen and Zhang (33).
Biological control in the absence of antagonism. To eliminate mechanisms of antagonism in $\mathrm{C} 3$, washed cell suspensions were heated in a water bath at $70^{\circ} \mathrm{C}$ for $20 \mathrm{~min}$, thus killing the cells. Cells were tested for viability by plating onto TSA. The cell suspensions also were tested for direct inhibition of fungal growth by applying $50-\mu \mathrm{l}$ volumes of cell suspension to four points on the periphery of TSA plates, inoculating each plate in the center with a mycelial plug of $B$. sorokiniana, and examining the cultures daily for development of inhibition zones around each bacterial inoculation point. The cell suspensions also were tested for direct effects on conidial germination by mixing equal volumes of cell suspension and B. sorokiniana conidial suspension in the wells of microtiter plates. After the microtiter plates were incubated at $25^{\circ} \mathrm{C}$ for $8 \mathrm{~h}$, conidial germination in each well was determined under a dissecting microscope. In all of these procedures, suspensions of live C3 cells and SDW were used as controls.

An experiment was conducted to determine the effects of foliar treatment with heat-killed $\mathrm{C} 3$ cells on the germination of $B$. sorokiniana on leaf surfaces and on the development of Bipolaris leaf spot. Suspensions of live or heat-killed cells of C3 were sprayed onto pots of turf $(15 \mathrm{ml}$ per pot) with a hand-pumped sprayer. For the control, pots of turf were sprayed with SDW. There were three replicate pots per treatment placed in the growth chamber in a randomized block design. Four days after bacterial applications, B. sorokiniana conidia were dusted onto the turf (30 mg of conidia per pot). Relative humidity in the growth chamber was kept at $>93 \%$ for $24 \mathrm{~h}$ after pathogen inoculation to favor conidial germination and then restored to alternating conditions. Twenty-four hours after inoculation with conidia, 10 leaves were collected from each pot for determining pathogen conidial germination frequency. Five 1-cm-long segments from each leaf were assayed for conidial germination. After pots of turf were incubated in the growth chamber for 6 days following pathogen inoculation, infection frequency and disease severity were measured. Ten grass leaf blades were collected at random from each pot. The number of lesions on each leaf blade was counted, and the linear length of each leaf blade was measured. Infection frequency was calculated as the total number of lesions in a sample divided by the total leaf length in the same sample. Disease severity (percent leaf area exhibiting lesions and chlorosis) was estimated for each leaf blade, and measurements from each pot were averaged prior to statistical analysis. The experiment was performed two times. Results from each repetition were subject separately to analysis of variance. After variances were found to be homogeneous, data from the two repetitions were subjected to pooled analysis of variance (ANOVA). Tukey's HSD test was used for separation of the treatment means.

Experiments on spatial and temporal separation of inducer and response. Three experiments were conducted to determine if C3 could inhibit pathogen conidial germination and disease development locally and when spatially and temporally separated from the pathogen. The first two experiments involved application of C3 to leaves of individual tall fescue plants, each having three leaves. In experiment 1 , induction treatment (live or heat-killed cells of C3) and challenge inoculation with the pathogen occurred on the same leaf. The distal, medial, or basal $1.5-\mathrm{cm}$ portion of the adaxial surface of the second fully expanded leaf was painted with a cell suspension using a soft brush. This procedure deposited $\approx 10 \mu \mathrm{l}$ of suspension or $10^{5}$ cells per centimeter of leaf. Controls were leaves in which the entire adaxial surface was treated with SDW. The painted leaves were kept in a horizontal position until the painted portions had dried and then placed upright in the growth chamber for $2 \mathrm{~h}$ or $1,2,4$, or 10 days prior to being inoculated with $B$. sorokiniana. Conidia ( $\approx 50$ per centimeter of leaf) were dusted onto the entire adaxial surfaces of the treated leaves while the leaves were positioned horizontally. On each challenge inoculation date, six leaves were inoculated per treatment. The inoculated plants were placed under constant high humidity for 
24 h. Afterward, 1-cm-long segments were excised aseptically from the basal, medial, and distal portions of each inoculated leaf and each segment was assayed for $\mathrm{C} 3$ population and conidial germination. There were two nontreated segments and one treated segment assayed from each leaf treated with a cell suspension. Data from the two nontreated segments were averaged prior to statistical analysis. Leaves on additional plants were treated and challenge inoculated; the abaxial and adaxial surfaces of these leaves were imprinted onto the $\mathrm{C} 3$-selective medium and potato dextrose agar to confirm that $\mathrm{C} 3$ and $B$. sorokiniana were restricted to the adaxial surfaces. This experiment was conducted twice. Data sets from each repetition and each inoculation date were analyzed separately by ANOVA. Each data set first was analyzed by comparing germination frequencies among all possible combinations of leaf segment (treated or nontreated), treatment material (live cells, heat-killed cells, or distilled water) and treatment location (basal, medial, or distal portion). A subsequent analysis was performed in which segments from leaves that were treated with live or heat-killed cells were categorized as treated or nontreated regardless of the location of the treatment.

In experiment 2, the effects of treating a single leaf with $\mathrm{C} 3$ was examined in relation to pathogen conidial germination and leaf spot development on neighboring leaves of the same plant (i.e., systemic effect). Suspensions of live and heat-killed C3 cells were painted onto the entire adaxial surface of the second fully expanded leaf of each plant. At 1, 5, 10, or 15 days after treatment applications, the first, second, and third fully expanded leaves on each plant were challenge inoculated by dusting the adaxial leaf surfaces with pathogen conidia. One day after challenge inoculation, C3 population size and conidial germination were determined from each of the three inoculated leaves as described above. The experiment was conducted twice. The data was subjected to ANOVA and Tukey's HSD test was used for separation of treatment means.

In experiment 3 , the effects of root treatment with $\mathrm{C} 3$ on pathogen germination and disease development in the foliage were evaluated. The roots in pots of turf were drenched with $70 \mathrm{ml}$ of suspension containing live or heat-killed cells of $\mathrm{C} 3$ or distilled water. At 1, 5, 10, and 15 days after bacterial applications, the foliage in four pots per treatment was inoculated with conidia of B. sorokiniana and, 1 day later, assayed for $\mathrm{C} 3$ numbers and conidial germination. $\mathrm{C} 3$ populations on the roots also were estimated by removing a sample of roots from the potting medium in each pot and washing the roots in $5 \mathrm{ml}$ of sterile phosphate buffer for dilution plating. Root populations of C3 were expressed as $\log _{10}$ CFU g ${ }^{-1}$ dry weight of root. Leaf spot incidence and severity were measured 6 days after inoculation. The experiment was conducted twice. Results were subjected to ANOVA, and Tukey's HSD test was used for separation of treatment means.

Evaluation of dose-response relationship. Suspensions of live $\mathrm{C} 3$ cells were sprayed onto the foliage of tall fescue turf, with each pot of turf receiving $\approx 20 \mathrm{ml}$ of bacterial suspension. Pots of turf were sprayed with distilled water as the control. Dry $B$. sorokiniana conidia were dusted onto the plants $(\approx 50$ spores per $\mathrm{cm}$ of leaf) $2 \mathrm{~h}$, or $1,4,7$, or 10 days after C3 application. Three pots per treatment were inoculated with the pathogen on each date. Throughout the experiment, pots were kept in the growth chamber in a randomized complete block design. Twenty-four hours after challenge inoculation with conidia, 10 fully expanded, horizontally oriented leaves of similar age and size $(4.5 \mathrm{~cm}$ long and $0.3 \mathrm{~cm}$ wide) were collected at random from the three inoculated pots for each treatment. Each leaf was cut transversely into $150.3-\mathrm{cm}$-long segments and each segment was assayed individually for C3 population level and conidial germination. Each leaf segment was considered to be a replicate, with the maximum number per treatment being 150 . Ten conidia per leaf segment was established as the minimum number for determining germination; therefore, segments with $<10$ conidia were excluded from statisti- cal analyses. Most leaf segments contained $\approx 20$ conidia. Data from each inoculation date were analyzed separately using two methods. In one method, the $\mathrm{C} 3$ population number detected on each C3-treated leaf segment was plotted against the frequency of $B$. sorokiniana conidial germination measured on that same segment. The relationship between $\mathrm{C} 3$ population size (dose) and the frequency of conidial germination (response) was determined by inspection and linear correlation analyses. Data points in which C3 was at nondetectable levels (i.e., 0 Log CFU), were not included in the correlation analysis. In the other method, the $F$ test was used to compare conidial germination on segments from C3treated leaves with the control. The experiment was conducted twice.

Evaluation of host and pathogen specificity. To determine whether or not the induced resistance-related effects of $\mathrm{C} 3$ were specific to tall fescue, two experiments also were conducted on winter wheat 'Scout 66', which was susceptible to the isolate of $B$. sorokiniana used in this study. Wheat plants were grown in separate pots in a greenhouse for approximately 3 weeks to the two-fully-expanded-leaf stage. In one experiment, suspensions of heat-killed or live $\mathrm{C} 3$ cells were sprayed onto the foliage of five plants. As the control, wheat plants were sprayed with distilled water. After the treated plants were incubated in the growth chamber for 4 days, B. sorokiniana conidia were dusted onto the foliage and the plants were returned to the growth chamber for 6 days. Two leaves were collected from each plant for determination of disease incidence and severity. In the second experiment, suspensions of heat-killed or live C3 cells, or SDW, were painted onto the adaxial surface of the basal $2-\mathrm{cm}$ portion of the second fully expanded leaf. There were five replicate wheat plants per treatment. Four days after treatment applications, the entire adaxial surface of the treated leaves were dusted with $B$. sorokiniana conidia ( $\approx 50$ per $\mathrm{cm}$ leaf). $\mathrm{C} 3$ population and conidial germination assessments were performed as described above.

An experiment also was conducted to determine if induced resistance caused by $\mathrm{C} 3$ could be effective against a different tall fescue pathogen, $R$. solani. Pots of tall fescue turf were sprayed with suspensions of live or heat-treated cells of $\mathrm{C} 3$, or with distilled water as the control. There were six replicate pots per treatment. Treated pots were incubated at $23^{\circ} \mathrm{C}$ under fluorescent lights on a diurnal cycle for 4 days. Each pot of turf was inoculated with $0.1 \mathrm{~g}$ of autoclaved tall fescue seed colonized by $R$. solani AG1-IA isolate R251 (8) scattered across the surface of the potting medium. The inoculated pots were placed in shallow trays with water, which then were enclosed in large plastic bags to form moisture chambers. The trays were placed under diurnal lighting for 4 days, after which the percent leaf area exhibiting blight was visually assessed.

Each of the three experiments described above was conducted twice. Pooled results were analyzed by ANOVA following testing of homogeneity of error variances, and means were separated using Tukey's HSD test.

Measurement of peroxidase activity. Effects of foliage and root applications of $\mathrm{C} 3$ on peroxidase activity on leaves were tested separately. Suspensions of heat-killed or live C3 cells were either sprayed onto foliage of tall fescue turf or applied to roots by drenching into the soil as described above. As the control, plants were treated with SDW. There were two replicate pots of turf per treatment and sampling day for each type of application. Twelve leaf blades at the same developmental stage were sampled from each pot of turf $(\approx 1 \mathrm{~g}$ of fresh tissue) starting $2 \mathrm{~h}$ after treatment applications and subsequently at daily intervals for 15 days. The samples were stored immediately at $-20^{\circ} \mathrm{C}$ until extraction. Enzyme extraction and peroxidase activity measurements were performed according to Stadnik and Buchenauer (22). Guaiacol (2-methoxy-phenol) was used as the peroxidase substrate. Absorbance of the enzyme extract-substrate mixture was measured at $470 \mathrm{~nm}$ over a 3-min period with a spectrophotometer. Enzyme 
activity was expressed as the change in absorbance per minute per gram fresh weight of leaves. $\mathrm{H}_{2} \mathrm{O}_{2}$ and guaiacol were omitted from the blank cuvette. The negative controls were extracts from distilled water-treated leaves, and heat-killed and live C3 cells. Data collected at each sampling date following foliage applications and root applications were analyzed separately by ANOVA. Fisher's least significant difference test was used for the mean comparison. The experiment was conducted twice.

\section{RESULTS}

Biological control in the absence of antagonism. While heattreated C3 cell suspensions did not inhibit B. sorokiniana hyphal growth on TSA or have any effect on B. sorokiniana conidial germination (data not shown), treatment of tall fescue foliage with heat-killed cells resulted in a lower frequency of B. sorokiniana conidial germination on leaf surfaces and reduced leaf spot incidence and severity compared with the distilled water control (Table 1). Live C3 cells were more inhibitory to conidial germination and leaf spot development than heat-killed cells.

Spatial and temporal separation of inducer and pathogen inhibition. In experiment 1, application of live or heat-killed cells

TABLE 1. Effects of live and heat-killed cells of Lysobacter enzymogenes strain C3 on germination of Bipolaris sorokiniana conidia on tall fescue leaves and development of Bipolaris leaf $\operatorname{spot}^{\mathrm{w}}$

\begin{tabular}{lccc}
\hline Treatment $^{\mathrm{x}}$ & $\begin{array}{c}\text { Germination } \\
(\%)^{\mathrm{y}}\end{array}$ & $\begin{array}{c}\text { Disease incidence } \\
(\text { lesions } / 10 \mathrm{~cm} \text { of leaf })^{\mathrm{z}}\end{array}$ & $\begin{array}{c}\text { Disease severity } \\
(\% \text { leaf area })^{\mathrm{z}}\end{array}$ \\
\hline Live C3 cells & $15 \mathrm{c}$ & $27 \mathrm{c}$ & $15 \mathrm{c}$ \\
Killed C3 cells & $31 \mathrm{~b}$ & $43 \mathrm{~b}$ & $34 \mathrm{~b}$ \\
Distilled water & $84 \mathrm{a}$ & $88 \mathrm{a}$ & $76 \mathrm{a}$ \\
\hline
\end{tabular}

${ }^{w}$ Data followed by the same letter in each column are not significantly different $(P=0.05)$ according to Tukey's HSD test.

${ }^{x}$ Live and killed $\left(70^{\circ} \mathrm{C}, 20 \mathrm{~min}\right)$ cells were suspended in sterile distilled water to $5 \times 10^{8} \mathrm{CFU} / \mathrm{ml}$.

y Inoculation with conidia of $B$. sorokiniana occurred 4 days after treatment applications. Conidial germination was determined $24 \mathrm{~h}$ after pathogen inoculation. Values are means from two experiments, each with three replications.

${ }^{z}$ Measured 6 days after pathogen inoculation. Values are means from two experiments, with two and three replications.

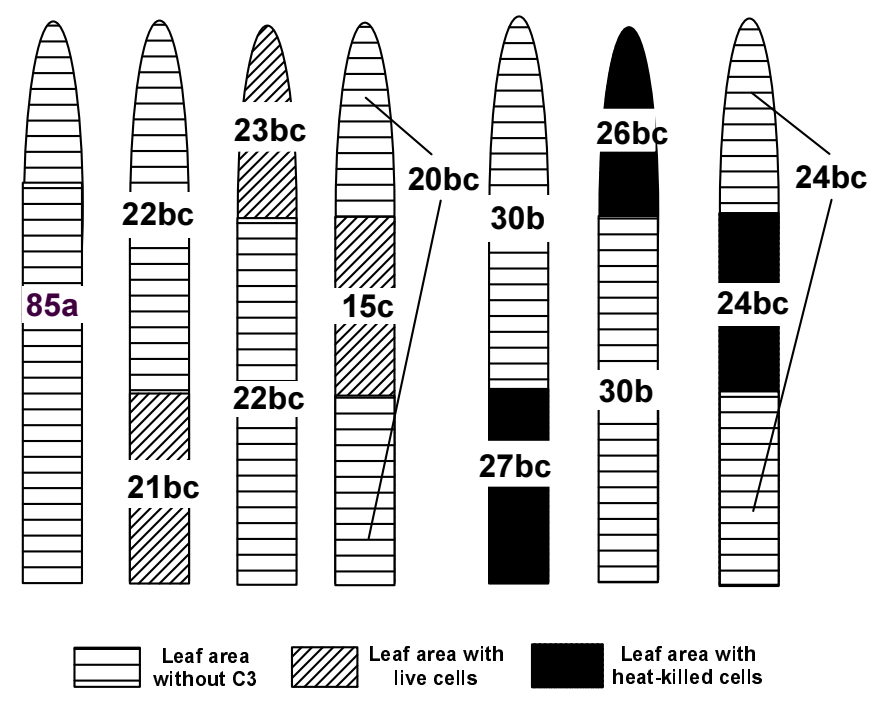

Fig. 1. Germination (\%) of conidia of Bipolaris sorokiniana on the adaxial surface of tall fescue leaves as affected by the application of live or heatkilled cells of Lysobacter enzymogenes strain C3 to different portions of the adaxial surface. B. sorokiniana conidia were dusted on leaf surfaces 2 days after bacterial applications. Results followed by the same letter are not significantly different $(P=0.01)$ according to Tukey's HSD test. of C3 to any portion of a tall fescue leaf inhibited germination of B. sorokiniana conidia along the entire length of the treated leaf. For example, when leaves were challenge inoculated with pathogen conidia 2 days after bacterial cell treatments, frequencies of conidial germination on both treated and nontreated segments from leaves treated with live or heat-killed C3 cells were lower $(P<0.01)$ than on leaves treated with distilled water, regardless of where (basal, medial, or distal leaf portion) the cell suspensions were applied (Fig. 1). Furthermore, there were no significant differences in conidial germination between nontreated and treated leaf segments for either treatment involving C3 cells. The inhibitory effect was dependent upon the time interval between application of bacterial cells and inoculation with conidia (Fig. 2). When leaves were inoculated $2 \mathrm{~h}$ after bacterial application, frequency of conidial germination on segments treated with live or heat-killed C 3 cells was reduced compared with the distilled water control, but germination on nontreated segments of treated leaves was the same as in the control. When pathogen inoculation occurred 1 day after bacterial treatment, inhibition of conidial germination was apparent on both nontreated and treated segments of leaves painted with live C3 cells. When the interval between treatment and challenge inoculation was extended to 2 days or longer, inhibition of conidial germination was found on nontreated segments of all leaves treated with $\mathrm{C} 3$ regardless of the viability of the bacterial cells. C3 and B. sorokiniana were detected only on the adaxial leaf surfaces to which they were applied. Furthermore, C3 was not detected on any leaf segment that had not been painted with live cells of C3. Similar results were obtained when this experiment was repeated.
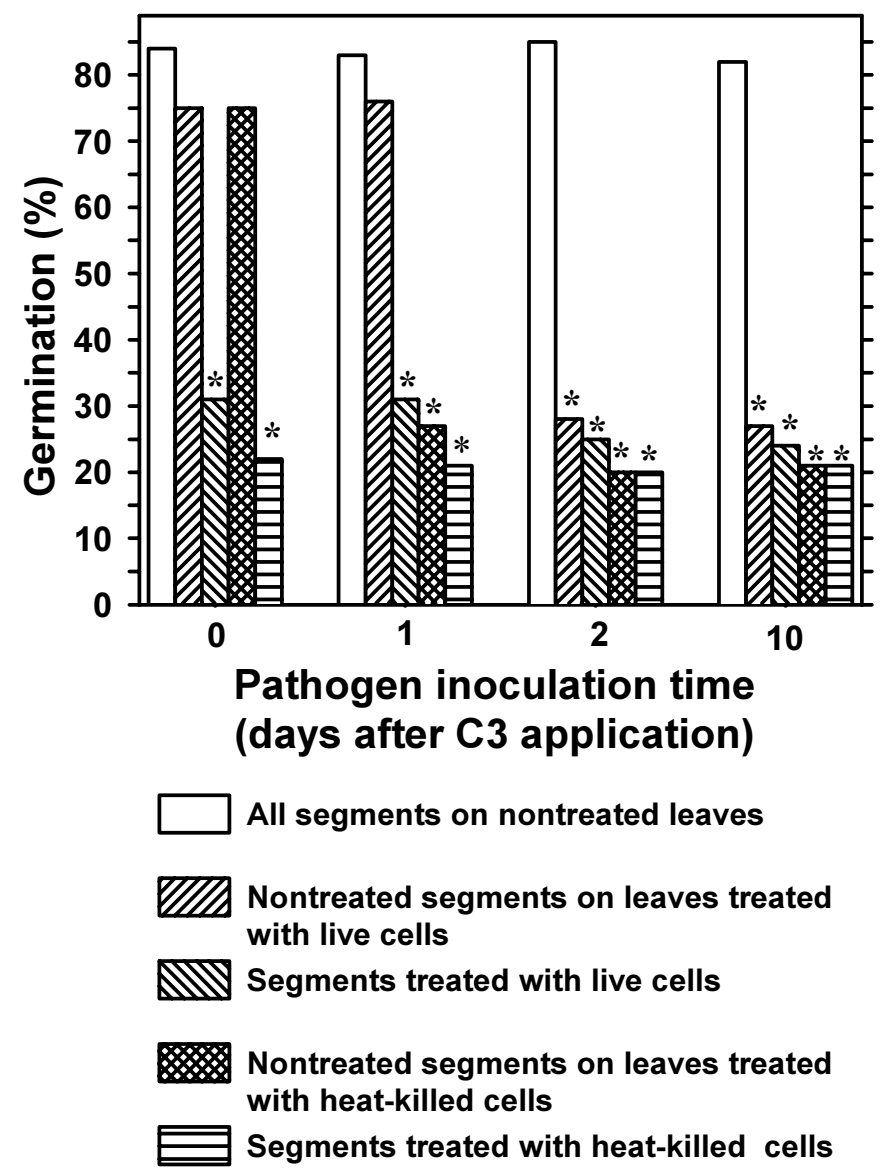

Fig. 2. Germination of Bipolaris sorokiniana conidia on tall fescue leaf segments following inoculation at various intervals after application of live or heat-killed cells of Lysobacter enzymogenes strain C3 to leaf surfaces. Asterisk denotes treatment being significantly different $(P=0.05)$ from the nontreated control according to Tukey's HSD test. 
In experiment 2, application of live or heat-killed cells of $\mathrm{C} 3$ to a tall fescue leaf had no inhibitory effect on germination of $B$. sorokiniana conidia on neighboring leaves of the same plant regardless of the time interval between the bacterial treatments and pathogen inoculation (data not shown). Conidial germination, averaged across all challenge inoculation dates, on the first and third leaves of C3-treated plants $(76 \pm 14 \%$ SD) was the same as on leaves of nontreated plants $(76 \pm 16 \% \mathrm{SD})$, whereas germination on $\mathrm{C} 3$-treated leaves $(24 \pm 13 \% \mathrm{SD})$ was significantly reduced $(P<0.05)$ in comparison.

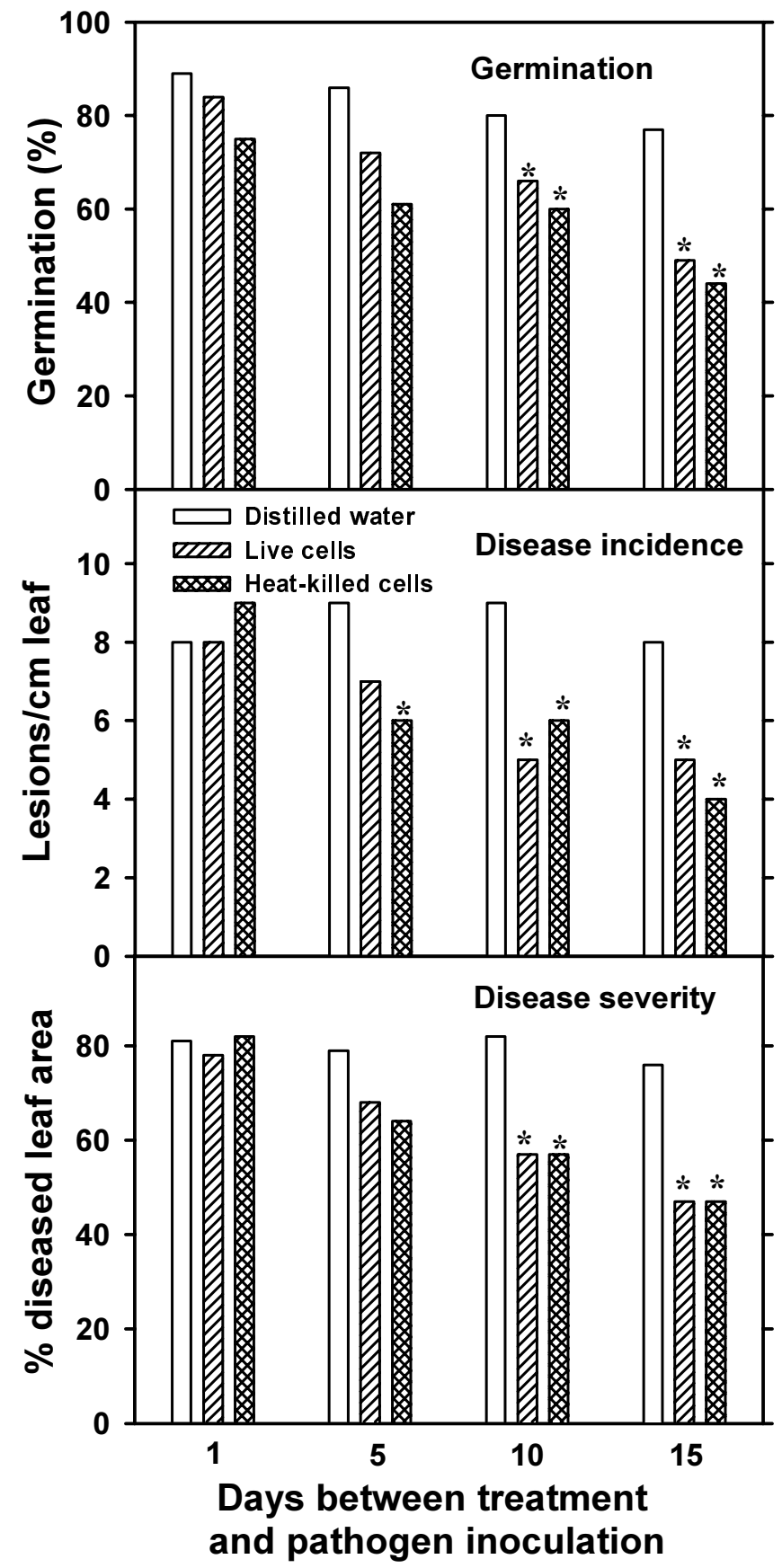

Fig. 3. Effects of root treatment with live or heat-killed cells of Lysobacter enzymogenes strain $\mathrm{C} 3$ on germination of Bipolaris sorokiniana conidia on tall fescue leaves and on development of Bipolaris leaf spot. Inoculation with conidia occurred $1,5,10$, and 15 days after root treatment. Conidial germination was determined $24 \mathrm{~h}$ and disease incidence and severity were measured 6 days after pathogen inoculation. Asterisk denotes a treatment being significantly different $(P=0.01)$ from distilled water-treated control according to Tukey's HSD test. Values are means from two experiments, each with three replicate measurements for germination and four for disease incidence and severity.
Application of live or heat-killed cells of C3 to tall fescue roots resulted in inhibited germination of B. sorokiniana conidia on the leaves and reduced leaf spot incidence and severity compared with distilled water controls. The inhibitory effects were not apparent until after an interval of more than 5 days between bacterial treatment and pathogen inoculation (Fig. 3). Germination and disease measurements in both $\mathrm{C} 3$ treatments were lower than the distilled water controls on day 5 , but only disease incidence in the heat-killed C3 treatment was significantly different from the control; there were no differences between treatments with live and heat-killed cells. When inoculation occurred 10 or 15 days after C3 root treatments, conidial germination and disease measurements in the bacterial treatments were significantly lower than in the distilled water control. The mean population of $\mathrm{C} 3$ found on roots of plants treated with live $\mathrm{C} 3$ was $6.6 \log \mathrm{CFU} \mathrm{g^{-1 }}$ dry weight 1 day after application, declining to $3.1 \log \mathrm{CFU} \mathrm{g}{ }^{-1}$ dry weight by 16 days after applications (data not shown). Similar results were obtained when the experiment was repeated.

Dose-response relationships between $\mathrm{C} 3$ and conidial germination. The relationship between $\mathrm{C} 3$ population number and conidial germination frequency, measured on $0.3-$ by- $0.3-\mathrm{cm}$ leaf segments, varied depending upon the time between $\mathrm{C} 3$ treatment and pathogen inoculation (Fig. 4). When leaves were inoculated with pathogen conidia $2 \mathrm{~h}$ after $\mathrm{C} 3$ application, conidial germination frequency on segments of $\mathrm{C} 3$-treated leaves was negatively correlated $(r=-0.73, P<0.001)$ with $\mathrm{C} 3$ population numbers on the same leaf segments (Fig. 4A). However, no relationship was found when inoculation with conidia was delayed by 1 day or

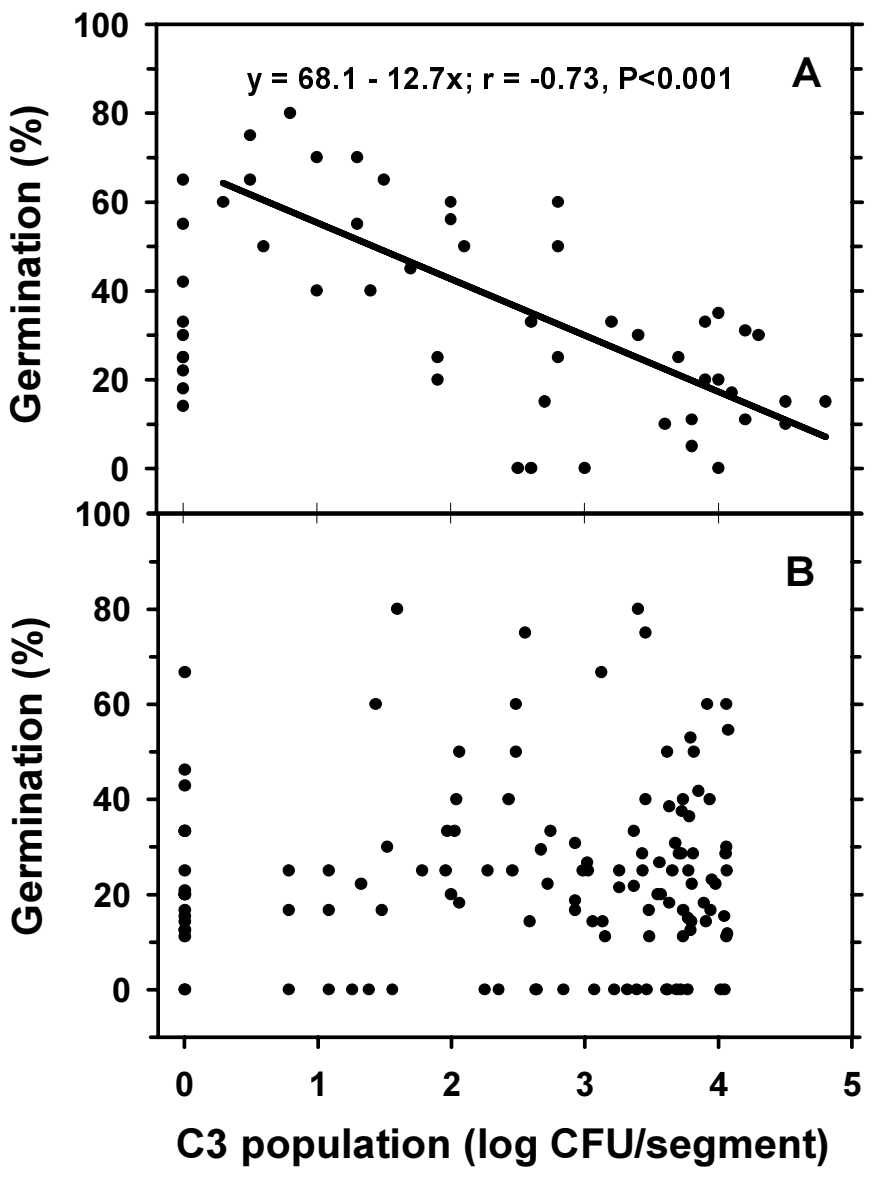

Fig. 4. Germination of Bipolaris sorokiniana conidia versus population size of Lysobacter enzymogenes strain C3 measured on 0.3-by-0.3-cm segments of tall fescue leaves inoculated with pathogen conidia $\mathbf{A}, 2 \mathrm{~h}$ and $\mathbf{B}, 10$ days after C3 application. Conidial germination and C3 population size were determined 1 day after pathogen inoculation. Data at " $0 \log$ CFU" denote nondetectable $\mathrm{C} 3$ and were excluded from correlation analysis. 
longer, such as on day 10 (Fig. 4B). Although the mean C3 population size per segment remained constant between 2.2 and $2.7 \log \mathrm{CFU}$ over 11 days following C3 application (data not shown), populations of $\mathrm{C} 3$ were nonuniform across segments, ranging from nondetectable to $>4 \log \mathrm{CFU}$ per segment. In the same experiment, germination of $B$. sorokiniana conidia on $\mathrm{C} 3-$ treated leaf segments was reduced $(P<0.05)$ compared with distilled water-treated controls regardless of the interval between C3 treatment and challenge inoculation (data not shown). Mean germination frequencies on $\mathrm{C} 3$-treated leaves ranged from 18 to $34 \%$ during the course of the experiment, compared with 76 to $83 \%$ in the control. Similar results were obtained when the experiment was repeated.

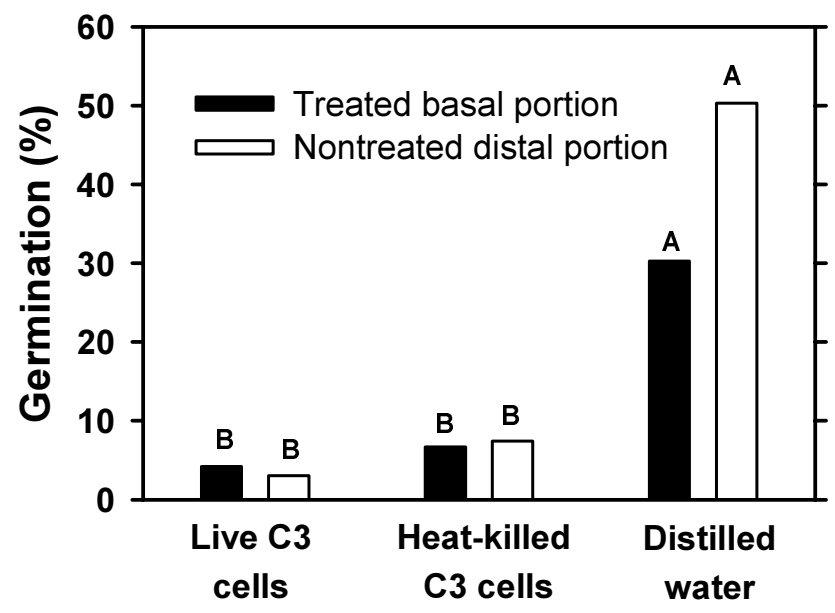

Fig. 5. Germination of Bipolaris sorokiniana conidia on basal and distal portions of wheat leaves treated with live or heat-killed cells of Lysobacter enzymogenes strain $\mathrm{C} 3$ or with distilled water. Pathogen inoculation occurred 4 days after treatment. Results with the same letter are not significantly different according to Tukey's HSD test at $P=0.01$. Values are means of two experiments, each with five replications.

TABLE 2. Effects of live and heat-killed cells of Lysobacter enzymogenes strain $\mathrm{C} 3$ on leaf spot in wheat caused by Bipolaris sorokiniana ${ }^{\mathrm{x}}$

\begin{tabular}{|c|c|c|}
\hline Treatment $^{\mathrm{y}}$ & $\begin{array}{l}\text { Disease incidence } \\
\text { (lesions } / 10 \mathrm{~cm} \text { of leaf) }\end{array}$ & $\begin{array}{c}\text { Disease severity } \\
(\% \text { leaf area })^{\mathrm{z}}\end{array}$ \\
\hline Live C3 cells & $4 \mathrm{~b}$ & $1 \mathrm{~b}$ \\
\hline Killed C3 cells & $6 \mathrm{~b}$ & $2 \mathrm{~b}$ \\
\hline Distilled water & $41 \mathrm{a}$ & $13 \mathrm{a}$ \\
\hline
\end{tabular}

${ }^{x}$ Data followed by the same letter in each column are not significantly different $(P=0.05)$ according to Tukey's HSD test.

${ }^{y}$ Live and killed $\left(70^{\circ} \mathrm{C}, 20 \mathrm{~min}\right)$ cells were suspended in sterile distilled water to $5 \times 10^{8} \mathrm{CFU} / \mathrm{ml}$.

${ }^{\mathrm{z}}$ Inoculation with conidia of B. sorokiniana occurred 4 days after treatment applications. Disease incidence and severity were measured 6 days after pathogen inoculation. Values are means from two experiments with five replications each.

TABLE 3. Effects of live and heat-killed cells of Lysobacter enzymogenes strain $\mathrm{C} 3$ on leaf blight in tall fescue caused by Rhizoctonia solani

\begin{tabular}{lc}
\hline Treatment $^{\mathrm{y}}$ & Percent blighted leaf area $^{\mathrm{z}}$ \\
\hline Live C3 cell suspension & $20 \mathrm{~b}$ \\
Heat-killed C3 cell suspension & $35 \mathrm{~b}$ \\
Sterile distilled water & $74 \mathrm{a}$
\end{tabular}

${ }^{y}$ Live and heated $\left(70^{\circ} \mathrm{C}, 20 \mathrm{~min}\right)$ cells were suspended in sterile distilled water to $5 \times 10^{8} \mathrm{CFU} / \mathrm{ml}$

${ }^{\mathrm{z}}$ Pots of turf were inoculated with pathogen-colonized seed 4 days after bacterial treatment. Disease severity was measured 4 days after pathogen inoculation. Values are means from two experiments, each with six replications. Data followed by the same letter in each column are not significantly different $(P=0.01)$ according to Tukey's HSD test.
Effects of C3 on other host-pathogen systems. Live and heatkilled cells of $\mathrm{C} 3$ provided similar protection against $B$. sorokiniana on wheat as on tall fescue. Application of live or heatkilled cells of $\mathrm{C} 3$ to only the basal portion of a wheat leaf resulted in less $(P<0.01)$ germination of $B$. sorokiniana conidia on along the entire length of the treated leaf compared with the distilled water control (Fig. 5). In addition, both live and dead C3 cells sprayed onto wheat plants reduced Bipolaris leaf spot development compared with SDW (Table 2).

Applications of heat-killed or live $\mathrm{C} 3$ cells to tall fescue foliage reduced the severity of leaf blight, caused by $R$. solani, compared with the SDW-treated control (Table 3). Disease severity was lowest in the treatment with live $\mathrm{C} 3$ cells, but the difference from the heat-killed cell treatment was not significant.

Induction of peroxidase activity by C3. Application of $\mathrm{C} 3$ either to foliage or roots resulted in significantly $(P<0.01)$ higher levels of peroxidase activity in leaves compared with the watertreated controls (Fig. 6). Increased peroxidase activity in leaves was observed as early as $2 \mathrm{~h}$ after foliar applications of live or heat-killed C3 cells and lasted for 9 days. When roots were drenched with live or heat-killed C3 cells, increased peroxidase activity in leaves of treated plants was observed in 2 days and remained elevated throughout most of the experiment. Peroxidase levels were similar between treatments with live and heated C3

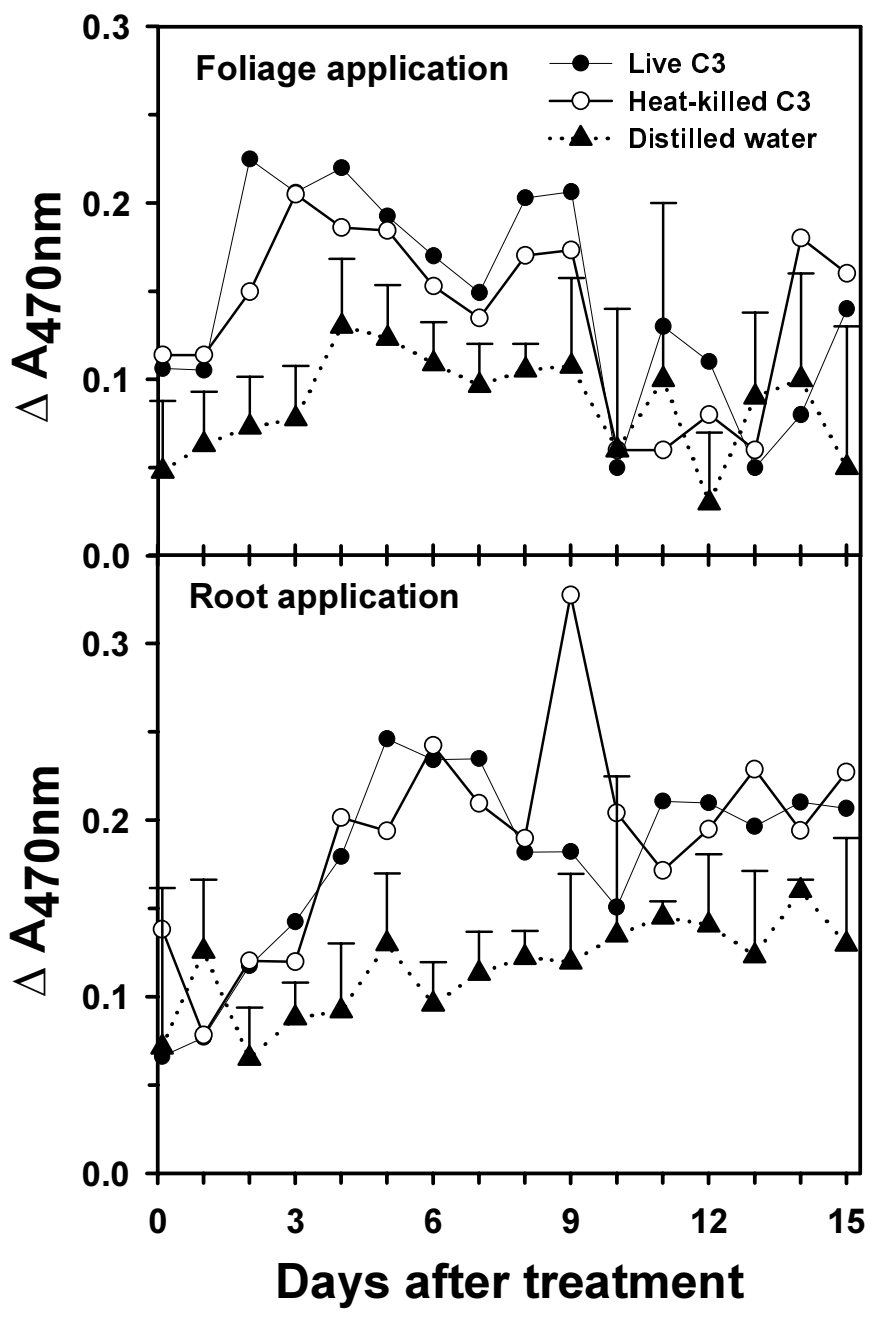

Fig. 6. Peroxidase activity (increase in absorbance per minute per gram of fresh weight) in tall fescue leaves following treatment of leaves and roots with suspensions of live or heat-killed cells of Lysobacter enzymogenes strain C3. Day 0 samples were collected $2 \mathrm{~h}$ after treatment. Values are means of two replications. Error bar attached to each control data point is the least significant difference at $P=0.01$ 
cells, except for a high value exclusively on day 9 following root treatment. A high degree of variability in peroxidase levels in the treatments and the control was found starting 9 days after the treatments, associated with the onset of senescence in some of the leaves. The experiment was repeated with data being collected only through day 10; similar results were obtained except that there was no steep increase in peroxidase levels on day 9.

\section{DISCUSSION}

In this study, we have demonstrated that induced resistance is a mechanism of biological control by L. enzymogenes strain C3. This is the first report of induced resistance being elicited by a strain of L. enzymogenes. The species has been considered to be an inhabitant of soil and fresh water (6); however, finding that strain C3 can induce resistance demonstrates that strains of $L$. enzymogenes can establish close associations with plants as well. An unusual finding was resistance induced by $\mathrm{C} 3$ causing an inhibition of conidial germination on the leaf surface. There are very few reports of induced resistance affecting prepenetration stages of pathogenesis, whereas many reports exist of the opposite, such as benzothiadizole having no effect on fungal spore germination (10). Chen et al. (5) reported that systemic resistance induced in the roots of cucumber by Pseudomonas spp. inhibited zoospore attachment and encystment, but had less of an effect on cyst germination of Pythium aphanidermatum. In soybean, resistance induced by a binucleate Rhizoctonia sp. was reported to affect hyphal growth by pathogenic $R$. solani on the surface of hypocotyls (18). In a case similar to that of $\mathrm{C} 3$, localized resistance against Helminthosporium (=Cochliobolus) carbonum race 1 induced in maize by prior inoculation with race 2 was associated with the production of unidentified compounds that reversibly inhibited conidial germination and germ tube elongation (4).

Proof of induced resistance having a role in biological control by $\mathrm{C} 3$ was based on the interactions of $\mathrm{C} 3$ with $B$. sorokiniana on tall fescue meeting five of the seven criteria proposed for verification of induced resistance $(23,27)$. We did not test for suppression of induced resistance using inhibitors of plant gene expression such as actinomycin D because inhibitors may affect bacteria and fungi as well (27). We also did not test for differences in induced resistance among host cultivars; this criterion is dependent upon there being different levels of resistance to B. sorokiniana among cultivars of tall fescue, but this information is unavailable. The first test criterion that was met, suppression of disease in the absence of direct toxic effects of the inducing agent on the challenge pathogen, was demonstrated using heat-killed cells of C3 that exhibited no inhibitory effects on hyphal growth and pathogen conidial germination in vitro. Use of heat-killed cells was the strategy employed in other biocontrol studies to examine the involvement of induced resistance and to separate it from antagonism mechanisms $(27,29)$. Heat-stable elicitor compounds produced by bacteria include cell membrane lipolysaccharides (29), Hrp proteins (25), and siderophores (14). Although the nature of the heat-stable elicitor produced by $\mathrm{C} 3$ has not been established, the fact that it can withstand heating rules out the possibility that induced resistance was due to chitinolysis by $\mathrm{C} 3$ chitinases producing oligomers that act as elicitors (21).

In testing the second criterion, that protection can occur locally and systemically, we found that application of C3 to a single leaf elicited localized resistance expressed down the length of the treated leaf, but induced systemic resistance only when it was applied to roots. This phenomenon has not been reported previously and deserves further investigation. It is conceivable that different elicitor-signaling pathway interactions might be involved in these two manifestations of resistance elicited by C3. Although we cannot rule out the possibility that the localized effect caused by live $\mathrm{C} 3$ cells was due to antifungal diffusing across the leaf surface, the fact that heat-killed cells produced both localized and systemic host responses is evidence that the localized effect was not due entirely to antifungal compounds.

We found the that third characteristic of induced resistance, the necessity of a time interval between application of the inducer and the onset of protection in the plant, applies to the induction of systemic resistance by $\mathrm{C} 3$, whereas localized resistance was expressed in less than 1 day following induction by C3. These findings are in line with most systems of localized and systemic induced resistance $(24,27)$.

The absence of a dose-response relationship, the fourth indication of induced host resistance, applied to biological control by $\mathrm{C} 3$ when pathogen inoculation was delayed by at least 1 day, a sufficient time interval for the induction of localized resistance. In examples of induced resistance elicited by PGPR, protection was apparent only when roots were colonized by PGPR at a threshold population size, and no increase in protection occurred with higher numbers of the inducer strain (19). Threshold populations for induction of resistance on leaves or roots by C3, or by any other phylloplane bacterium, have yet to be determined.

Nonspecificity of protection also is an important criterion of induced resistance, with many studies showing that induced resistance can enhance the defensive capacity in different host systems against different types of target organisms $(24,27)$. The fact that heat-killed cells of $\mathrm{C} 3$ inhibited infection by $B$. sorokiniana when applied to wheat and reduced the severity of leaf blight caused by $R$. solani when applied to tall fescue indicates that induced resistance by $\mathrm{C} 3$ is not limited to the tall fescue- $B$. sorokiniana interaction. We also have evidence that $\mathrm{C} 3$ can induce localized, but not systemic, resistance in common bean against Uromyces appendiculatus (G. Yuen, unpublished data), and this might have contributed to the effectiveness of $\mathrm{C} 3$ in controlling bean rust in the field (32).

In tall fescue, we found that foliage and root applications of heat-killed and live $\mathrm{C} 3$ cells can stimulate peroxidase activity on leaves, confirming that $\mathrm{C} 3$ can elicit a host response. In addition to being directly antifungal, peroxidases are involved in formation of lignin or lignin-containing papillae at infection sites and in generation of hydrogen peroxide and toxic radicals that may function as antimicrobial agents during the earliest defense response or oxidative burst (11). It is uncertain, however, whether peroxidase is a mechanism of resistance elicited by $\mathrm{C} 3$. Although induction of peroxidase activity by foliar application of $\mathrm{C} 3$ coincided with the onset of the localized resistance phenotype, peroxidase activity induced by root treatment preceded the expression of systemic resistance. Furthermore, peroxidase activity levels induced in treated plants were relatively low compared with the levels induced by rust on a resistant wheat cultivar (16). The low peroxidase activity levels induced by $\mathrm{C} 3$ are comparable to levels induced in a rust-susceptible cultivar in that study. There are no previous reports on peroxidase activity in tall fescue to provide a direct comparison to our data. Nevertheless, the fact that elevated peroxidase activity is associated with induced resistance by $\mathrm{C} 3$ provides a biochemical marker for future studies on $\mathrm{C} 3$-plant interactions.

Proof that C3 can induce resistance does not preclude antibiosis through its chitinases also being important in biological control. In some experiments (Table 1), treatment of foliage with live C3 cells, which presumably are active through both mechanisms, provided greater pathogen suppression than heat-killed cells. When Bipolaris conidia were deposited onto treated leaves shortly after C3 application in the dose response experiment (Fig. 5), germination was inversely related to the $\mathrm{C} 3$ population, which could reflect direct toxicity from antifungal compounds produced by $\mathrm{C} 3$. These findings support the hypothesis that both antagonism and induced resistance are involved in the biological control of Bipolaris leaf spot in tall fescue by $\mathrm{C} 3$, with induced resistance being manifested later than antagonism. There is a consensus that involvement of multiple mechanisms in a biological control agent 
could lead to more effective biological control (13). While the relative contribution of each mechanism possessed by $\mathrm{C} 3$ to its biocontrol efficacy in the field has yet to be determined, the action of dual mechanisms could explain the effectiveness of $\mathrm{C} 3$ in controlling a range of fungal pathogens over a wide range of conditions.

\section{ACKNOWLEDGMENTS}

This project was part of NC-125 Regional Project, "Biocontrol of soiland residue-borne plant pathogens." University of Nebraska, Agricultural Research Division Journal Series No. 13723. O. Kilic-Ekici was supported by a scholarship from the Republic of Turkey, Ministry of Education. We thank C. Jochum, A. Prokupek, and L. Tran for technical assistance, and G. Horst for providing clonal plant material.

\section{LITERATURE CITED}

1. Bargabus, R. L., Zidack, N. K., Sherwood, J. E., and Jacobsen, B. J. 2002. Characterization of systemic resistance in sugar beet elicited by a non-pathogenic, phyllosphere-colonizing Bacillus mycoides, biological control agent. Physiol. Mol. Plant Pathol. 61:289-298.

2. Braun-Kiewnick, A., Kiewnick, S., Jacobsen, B. J., and Sands, D. C. 1998. Induction of systemic resistance by antagonistic Bacillus sp. and the chemical inducer benzothiadiazole controls Cercospora leaf spot of sugar beet. (Abstr.) Phytopathology 88(suppl.):S10.

3. Braun-Kiewnick, A., Kiewnick, S., Jacobsen, B. J., and Sands, D. C. 1998. Induction of systemic resistance in barley by the plant activator benzothiadiazole and Pantoea agglomerans strains Eh 239 and Eh 460. (Abstr.) Phytopathology 88(suppl.):S10.

4. Cantone, F. A., and Dunkle, L. D. 1990. Involvement of an inhibitory compound in induced resistance of maize to Helminthosporium carbonum. Phytopathology 80:1225-1230.

5. Chen, C. Q., Belanger, R. R., Benhamou, N., and Paulitz, T. C. 1998. Induced systemic resistance (ISR) by Pseudomonas spp. impairs pre- and post-infection development of Pythium aphanidermatum on cucumber roots. Eur. J. Plant Pathol. 104:877-886.

6. Christensen, P., and Cook, F. D. 1978. Lysobacter, a new genus of nonfruiting, gliding bacteria with a high base ratio. Int. J. Syst. Bacteriol. 28:367-393.

7. Giesler, L. J. 1998. Environmental effects on bacterial strains applied to the turfgrass phylloplane. Ph.D. diss. University of Nebraska, Lincoln.

8. Giesler, L. J., and Yuen, G. Y. 1998. Evaluation of Stenotrophomonas maltophilia strain $\mathrm{C} 3$ for biocontrol of brown patch disease. Crop Prot. 17:509-513.

9. Giesler, L. J., Yuen, G. Y., and Horst, G. L. 2000. Canopy microenvironments and applied bacteria population dynamics in shaded tall fescue. Crop Sci. 40:1325-1332.

10. Gorlach, J., Volrath, S., Knauf-Beiter, G., Hengy, G., Beckhove, U., Kogel, K. H., Oostendorp, M., Staub, T., Ward, W., Kessmann, H., and Ryals, J. 1996. Benzothiadiazole, a novel class of inducers of systemic acquired resistance, activates gene expression and disease resistance in wheat. Plant Cell 8:629-643.

11. Hammerschmidt, R., and Nicholson, R. L. 1998. A survey of plant defense responses to pathogens. Pages 55-71 in: Induced Plant Defenses Against Pathogens and Herbivores. A. A. Agrawal, S. Tuzun, and E. Bent, eds. The American Phytopathological Society, St. Paul, MN.

12. Hammerschmidt, R., Nuckles, E. M., and Kuc, J. 1982. Association of enhanced peroxidase activity with induced systemic resistance of cucumber to Colletotrichum lagenarium. Physiol. Plant Pathol. 20:73-82.

13. Harman, G. E. 2000. Myths and dogmas of biocontrol: Changes in perceptions derived from research on Trichoderma harzianum T-22. Plant Dis. 84:377-393.

14. Leeman, M., den Ouden, F. M., van Pelt, J. A., Dirkx, F. P. M., Steijl, H., Bakker, P. A. H. M., and Schippers, B. 1996. Iron availability affects induction of systemic resistance to Fusarium wilt of radish by Pseudomonas fluorescens. Phytopathology 86:149-155.

15. Lyon, G. D., Reglinski, T., and Newton, A. C. 1995. Novel disease control compounds: The potential to immunize plants against infection. Plant Pathol. 44:407-427.
16. Macko, V., Woodbury, W., and Stahman, M. A. 1968. The effect of peroxidase on the germination and growth of mycelium of Puccinia graminis f. sp. tritici. Phytopathology 58:1250-1254.

17. Maurhofer, M., Hase, C., Meuwly, P., Metraux, J. P., and Defago, G. 1994. Induction of systemic resistance of tobacco to tobacco necrosis virus by the root-colonizing Pseudomonas fluorescens strain CHAO: Influence of the gacA gene and pyoverdine production. Phytopathology $84: 139-146$

18. Poromarto, S. H., and Nelson, B. D. 1998. Association of binucleate Rhizoctonia with soybean and mechanism of biocontrol of Rhizoctonia solani. Phytopathology 88:1056-1067.

19. Raaijmakers, J. M., Leeman, M., Van Oorschot, M. M. P., van der Sluis, I., Schippers, B., and Bakker, P. A. H. M. 1995. Dose-response relationship in biological control of Fusarium wilt of radish by Pseudomonas spp. Phytopathology 85:1075-1081.

20. Ramamoorthy, V., Viswanathan, R., Raguchander, T., Prakasam, V., and Samiyappan, R. 2001. Induction of systemic resistance by plant growth promoting rhizobacteria in crop plants against pests and diseases. Crop Prot. 20:1-11.

21. Roby, D., Gadelle, A., and Toppan, A. 1987. Chitin oligosaccharide as elicitors of chitinase activity in melon plants. Biochem. Biophys. Res. Commun. 143:885-892.

22. Stadnik, M. J., and Buchenauer, H. 2000. Inhibition of phenylalanine ammonia-lyase suppresses the resistance induced by benzothiadiazole in wheat to Blumeria graminis f. sp. tritici. Physiol. Mol. Plant Pathol. 57:23-34.

23. Steiner, U., and Schonbeck, F. 1995. Induced disease resistance in monocots. Pages 86-110 in: Induced Resistance to Disease in Plants. R. Hammerschmidt and J. Kuc, eds. Kluwer Academic Publishers, Dordrecht, the Netherlands.

24. Sticher, L., Mauchmani, B., and Betraux, J. P. 1997. Systemic acquired resistance. Annu. Rev. Phytopathol. 35:235-270.

25. Strobel, N. E., Ji, C., Gopalan, S., Kuc, J. A., and He, S. Y. 1996. Induction of systemic acquired resistance in cucumber by Pseudomonas syringae pv. syringae $61 \mathrm{HrpZ}_{\mathrm{Pss}}$ protein. Plant J. 9:432-439.

26. Sullivan, R. F., Holtman, M. A., Zylstra, G. J., White, J. F, Jr., and Kobayashi, D. Y. 2003. Taxonomic positioning of two biological control agents for plant diseases as Lysobacter enzymogenes based on phylogenetic analysis of $16 \mathrm{~S}$ rDNA, fatty acid composition and phenotypic characteristics. J. Appl. Microbiol. 94:1079-1086.

27. Van Loon, L. C., Bakker, P. A. H. M., and Pieterse, C. M. J. 1998. Systemic resistance induced by rhizosphere bacteria. Annu. Rev. Phytopathol. 36:453-483.

28. Van Peer, R., Niemann, G. J., and Schippers, B. 1991. Induced resistance and phytoalexin accumulation in biological control of Fusarium wilt of carnation by Pseudomonas sp. strain WCS417r. Phytopathology 81: 728-734.

29. Van Peer, R., and Schippers, B. 1992. Lipopolysaccharides of plantgrowth promoting Pseudomonas spp. strain WCS417r induce resistance in carnation to Fusarium wilt. Neth. J. Plant Pathol. 98:129-139.

30. Wei, Z., Laby, R. J., Zumoff, D. W., Bauer, D. W., He, S. Y., Collmer, A., and Beer, S. V. 1992. Harpin, elicitor of the hypersensitive response produced by the plant pathogen Erwinia amylovora. Science 257:85-88.

31. Yuen, G. Y., and Kilic, O. 2001. Evidence of induced resistance in the control of Bipolaris sorokiniana in tall fescue by Stenotrophomonas maltophilia C3. Int. Turfgrass Soc. Res. J. 9:736-741.

32. Yuen, G. Y., Steadman, J. R., Lingdren, D. T., Schaff, D., and Jochum, C. 2001. Bean rust biological control using bacterial agents. Crop Prot. 20:395-402.

33. Yuen, G. Y., and Zhang, Z. 2001. Control of brown patch disease using the bacterium Stenotrophomonas maltophilia strain C3 and culture fluid. Int. Turfgrass Soc. Res. J. 9:742-747.

34. Zhang, Z., and Yuen, G. Y. 1999. Biological control of Bipolaris sorokiniana on tall fescue by Stenotrophomonas maltophilia C3. Phytopathology 89:817-822.

35. Zhang, Z., and Yuen, G. Y. 2000. The role of chitinase production by Stenotrophomonas maltophilia strain C3 in biological control of Bipolaris sorokiniana. Phytopathology 90:384-389.

36. Zhang, Z., Yuen, G. Y., Sarath, G., and Penheiter, A. 2001. Chitinases from the plant disease biocontrol agent, Stenotrophomonas maltophilia C3. Phytopathology 91:204-211. 